\title{
Application of Energy-Saving Distiller for Standardized Patchouli Oil Production in Patchouli Oil Small Medium Enterprise (SME) in Kulon Progo
}

\author{
Karna Wijaya ${ }^{1 *}$, Widi Kurniawati ${ }^{1}$, Nasih Widya Yuwono ${ }^{2}$, Farida $^{1}$ \\ ${ }^{1}$ Chemistry Departement, Faculty of Mathematics and Natural Sciences dan, University of Gadjah Mada, Mlati, \\ Sleman, D.I. Yogyakarta, Indonesia \\ ${ }^{2}$ Agrotechnology Study Program, Faculty of Agriculture, University of Gadjah Mada, Depok, Sleman, D.I. \\ Yogyakarta, Indonesia
}

Submisi: 17 February 2020 ; Revisi: 26 June 2020; Penerimaan: 27 June 2020

Keywords:
Energy-efficient
SMEs
Standard
Nasional
Indonesia
Technology
transfer
Time-efficient

Abstract Patchouli oil is one of the export commodities with high economic value that attracts attention in the raw material business. To be marketed domestically as well as internationally, patchouli oil must meet the Standar Nasional Indonesia (SNI). Various patchouli oil processing techniques have been developed by researchers but only a few that meet the requirements of SNI. In this study, patchouli leaves were processed using an energy-saving distiller equipped with heat insulators. Patchouli oil was then treated using bentonite$\mathrm{NaHCO}_{3}$ composite adsorbent which was synthesized through a hydrothermal process followed by calcination. The program was executed by preparing of the distiller and adsorbent before applying them to Surya Wulan patchouli oil processing Small Medium Enterprise (SME). The adsorbent was prepared and analyzed at the Physical Chemistry Laboratory and the distiller was tested in CV. Fruitanol Energy, Yogyakarta. The result showed that the distiller has a capacity of $15 \mathrm{~kg}$, which can save costs up to $35.5 \%$ and $33.3 \%$ more efficient in time compared to the conventional technology in Surya Wulan SME. Patchouli oil produced successfully met SNI quality requirements and was certified by LPPT UGM. Furthermore, the adsorbent produced was able to reduce around $80 \%$ of the acid number of crude patchouli oil.

\section{INTRODUCTION}

The existence of patchouli oil is needed massively and sustainably in the cosmetics and perfume industry as a fixative. Approximately, $90 \%$ of today's global production of 1,200-1,300 metric tons per annum is exported by Indonesia (Howarth, 2015; Lawrence, 2009). Patchouli oil is an essential oil obtained from the distillation process of leaves, stems, and branches of patchouli plants. It is one of the essential oils whose function in cosmetics especially perfume industries cannot be replaced by other synthetic substances since it has an important role in determining the strength, properties, and durability of the aroma produced. Patchouli oil becomes a chemical substance or agent that stabilizes and preserves volatile components to bind scents of perfume so that it last longer (Kusuma et al., 2018). That is due to its characteristic that can form a harmonious aroma in a mixture, even it can be said to be perfume (Kusuma and Mahfud, 2016; Zhao et al., 2005). In the pharmaceutical industry, patchouli oil is used as an anti-inflammatory, anti-depressant, antifungal, and antibacterial (Blank et al., 2011; Setiawan and Rosman, 2013). The demand for patchouli oil strengthens the existence of patchouli oil business groups to continue to be existed and improve their production processes to manufacture products with high quality that meet Standar Nasional Indonesia (SNI) requirements (Table 1), in pursuance of entering the national and international market of patchouli oil. The export price of patchouli oil

ISSN 2460-9447 (print), ISSN 2541-5883 (online)

${ }^{*}$ Corresponding author : Karna Wijaya

Chemistry Departement, Faculty of Mathematics and Natural Sciences, University of Gadjah Mada, Sekip Utara, Bulaksumur, Senolowo, Sinduadi, Mlati, Sleman, 55284 D.I. Yogyakarta, Indonesia

Email:karnawijayal@ugml.ac.id 
reaches Rp. 600,000 to Rp. 800,000 per $\mathrm{kg}$ with a net profit of Rp. 370,000 per $\mathrm{kg}$ (Chaidir, 2009) which is much higher in value than the price of patchouli leaves of Rp 1,200 per kg (Marbun, 2014).

Table 1. SNI parameters of patchouli oil

\begin{tabular}{ll}
\hline Parameters & SNI \\
\hline Color & $\begin{array}{l}\text { light yellow-reddish } \\
\text { brown }\end{array}$ \\
Specific gravity & $0,950-0,975$ \\
Refractive index & $1,507-1,515$ \\
Solubility in ethanol & A clear solution in volume \\
$90 \%$ & ration of 1:10 \\
Acid number & Max. 5 \\
Ester number & Max. 20 \\
Optical rotation & $(-) 48^{\circ}-(-) 65^{\circ}$ \\
Patchouli alcohol $(\%)$ & Min. 30 \\
Fe content $(\mathrm{mg} / \mathrm{kg})$ & Max. 25
\end{tabular}

SNI: Standar Nasional Indonesia

Indonesia is one of the largest patchouli oil producers in the world and annually supplies around $70 \%$ to $90 \%$ of the world's need for oil. With such demand, patchouli oil processing plays a crucial role in the supply of patchouli oil. The final quality of patchouli oil is determined by factors that arise pre- and post-harvesting of the leaves. Pre-harvest factors include the type of patchouli plants, cultivation techniques, methods, and harvest time along with the surrounding environment. Meanwhile, post-harvest factors include handling methods, methods of processing, packaging, and storing.

Oil production in Surya Wulan Small Medium Enterprise (SME) currently still used firewood as its main fuel. Figure 1 shows the use of a furnace stove system that requires a continuous supply of wood and thus exhaustion of manpower. This caused the distillation process to be inefficient in terms of energy and time. According to the Head of Surya Wulan SME, they needed about more than 8 hours to distill patchouli leaves in one batch of the distillation process. Another main problem was that the oil produced had a relatively high acid number $(>5)$ and did not meet the SNI.

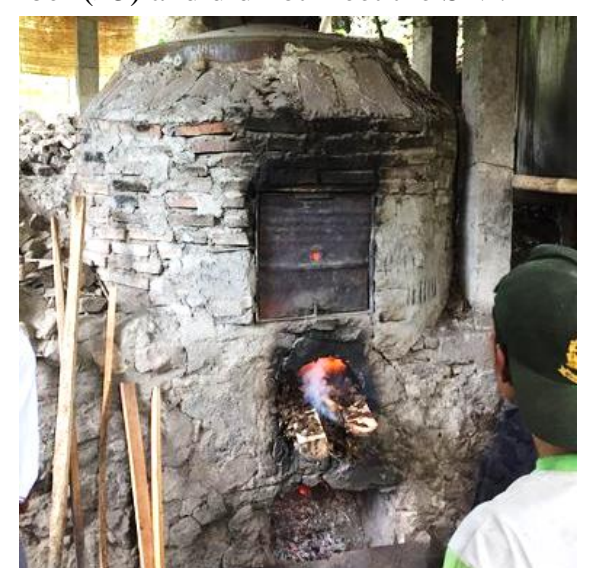

Figure 1. Distiller with a wood furnace in Surya Wulan SME
The distillation equipment owned by the SME was also used for the distillation of clove oil. Hence, a cleaning process is required before it could be used for the distillation of patchouli oil. Consequently, patchouli oil is sometimes contaminated by clove oil that automatically decreases its quality and results in the failure to meet the SNI. Therefore, another efficient distillation plant is highly necessary, especially in patchouli oil production. It needs to be simple and equipped with tools and materials for separation and purification.

The dissemination of the Appropriate Technology Program is expected to fulfill the wishes of Surya Wulan SME as the distilling technology offered was relatively simple and energy-efficient. The distilling installation provided was made of stainless steel equipped with a heat insulator. The heat insulator can reduce and prevent heat loss so that the distillation runs effectively. This technology was equipped with a patchouli oil purifier derived from bentonite $/ \mathrm{NaHCO}_{3}$ composite to produce more purified and high-quality products so that it could meet the SNI. The patchouli distiller and purifier installation had previously been developed by researchers at $\mathrm{CV}$. Fruitanol Energy and proven to be able to produce patchouli oil that meets SNI 06-23851998.

\section{METHODS}

The object of the patchouli oil distillation business study was Surya Wulan SME in Gerbosari Village, Samigaluh District, Kulonprogo Regency. The Appropriate Technology program provided was divided into three parts, namely (1) preparation and testing of distiller in CV. Fruitanol Energy, (2) preparation of patchouli oil processing and purification materials from bentonite and $\mathrm{NaHCO} 3$, and laboratory-scale refining of patchouli oil and (3) transfer of technology to Surya Wulan SME.

\subsection{Patchouli oil distillation plant}

The distillation plant offered consists of a gas stove, patchouli leaves the container, condenser, and patchouli oil purifier (Figure 2). The use of a gas stove aimed to shorten the distillation time since the heat will be more stable and evenly distributed, so the heating process will be more effective. the al, the heating process using a gas stove will save production costs since the owner does not have to buy tons of firewood and can pay the employee in a shorter time. Moreover, the SME can reduce the carbon footprint by using the energy-saving distiller.

This system is equipped with water flow valves and thermometers. The working principle of this system is to distill patchouli oil from dried patchouli leaves using water vapor obtained from the heating of water up to $100^{\circ} \mathrm{C}$. Water vapor will condensed and crude patchouli oil can be obtained. It is then separated from water 
through a separation installation. The distiller was tested first in CV. Fruitanol Energy before being transferred to Surya Wulan SME.

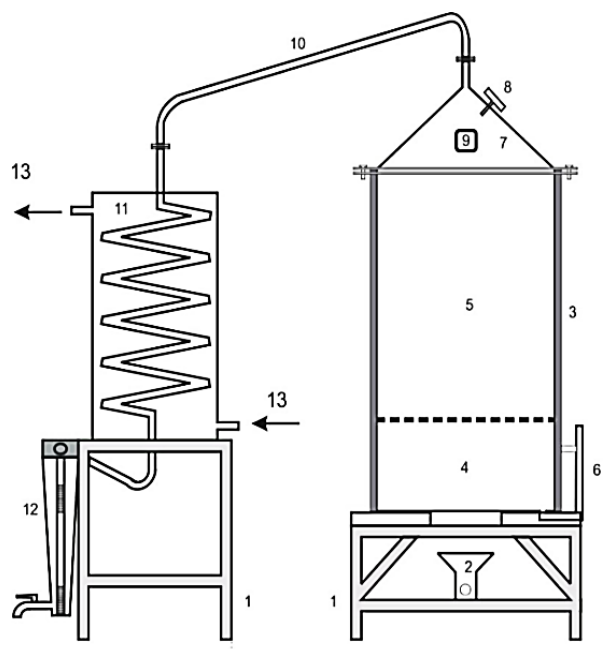

Description:

1. Iron frame

8. Thermometer

2. Gas stove

9. Handle

3. Distillation tube

10. Connector

4. Water space

11. Spiral condenser

5. Sample/leaves space

12. Oil and water separator

6. Water control

13. Water in and water out

7. Distillation tube cover

Figure 2. Design of energy-saving distiller that was ready to be applied

\subsection{Bentonite/ $\mathrm{NaHCO}_{3}$ composite adsorbent}

The use of adsorbent aims to reduce the acid number in patchouli oil so that it can meet the quality requirements of the SNI. This alkaline composite material will absorb Fe metal so that its level can decrease, consequently decreasing the acid number. The material with a 20/80 bentonite $/ \mathrm{NaHCO}_{3}$ ratio was manufactured through a calcination process at a temperature of $300^{\circ} \mathrm{C}$. The adsorbent material was shaped like a pellet, dried in an oven, and ready to be used to purify patchouli oil. The process of making adsorbent was carried out at the Physical Chemistry Laboratory of FMIPA UGM. Purification testing was done by adding $100 \mathrm{~g}$ of adsorbent into $5 \mathrm{~L}$ of crude patchouli oil and then gently stir for 5 hours. The mixture was allowed to stand for a while and then filtered and centrifuged. Furthermore, the patchouli oil that had been purified was tested at LPPT UGM.

\subsection{Transfer of technology to Surya Wulan SME}

The energy-saving distiller which was previously tested in CV. Fruitanol Energy has been handed over to Surya Wulan SME. Distiller operation training was also conducted at the SME together with patchouli oil entrepreneurs in Gerbosari Village, Samigaluh, Kulonprogo.

\section{RESULT AND DISCUSSION}

Patchouli oil distillation technique in Surya Wulan SME has used a boiler system with primary fuelwood. The process took a relatively long time and required a continuous supply of firewood so that it needed a high amount of power from the employee. However, patchouli oil produced still had a high acid number. The process might be simple since it was conventional, but there was a high loss of energy and the oil produced did not meet the SNI. Therefore, the Research-Based Community Service Grant and Utilization of Appropriate Technology Program in 2018 that was organized by the Directorate of Community Service UGM has facilitated the research team to introduce appropriate technology to Surya Wulan SME as an effort to overcome the problems faced by SME in patchouli oil production.

\subsection{Patchouli oil distillation system}

The research team has successfully introduced energysaving distillation technology with a steam system that is integrated with the condenser, water-oil separator, and purification materials so that patchouli oil produced would meet the SNI (Figure 3). This technology has a capacity of $15 \mathrm{~kg}$ of patchouli leaves, it was simple yet energy-efficient since the distillation process can be done in an hour (first oil drop) with Liquified Petroleum Gas (LPG) and can produce clear light-yellow patchouli oil. Figure 4 showed that the distiller has been successfully assembled and tested in CV. Fruitanol Energy. After being tested, the proposed distiller could extract oil from patchouli leaves in only 3-4 hours compared to the conventional one that needs more than 8 hours to distill patchouli leaves. The use of LPG has resulted in a shorter time of distillation process, less energy loss, less human power and exhaustion, lower production cost, and also a greener process that can reduce the carbon dioxide produced from burning firewood.

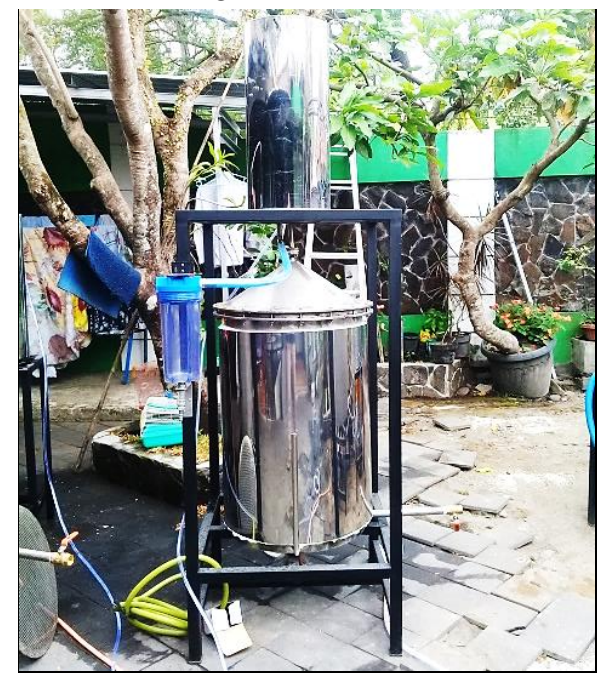

Figure 3. Patchouli oil distiller with a capacity $15 \mathrm{~kg}$ of dried patchouli leaves 
The use of gas as fuel in the technology allows workers to do not need to continuously supply wood, but merely replacing gas cylinders when necessary. One cylinder of $12 \mathrm{~kg}$ gas can be used up to 3 distillation processes with a capacity of $15 \mathrm{~kg}$ of dried patchouli leaves for each process.

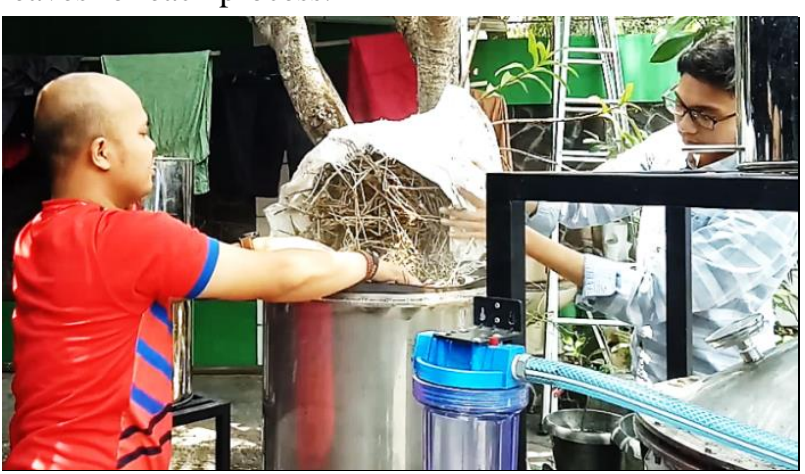

Figure 4. Distiller testing at CV. Fruitanol Energy

\subsection{Bentonite/ $\mathrm{NaHCO}_{3}$ adsorbent production}

Bentonite material was modified with $\mathrm{NaHCO}_{3}$ through a hydrothermal technique which aimed to increase its surface area and alkaline property thus making it more effective for $\mathrm{Fe}$ adsorption from oil and decrease its oil acid number.

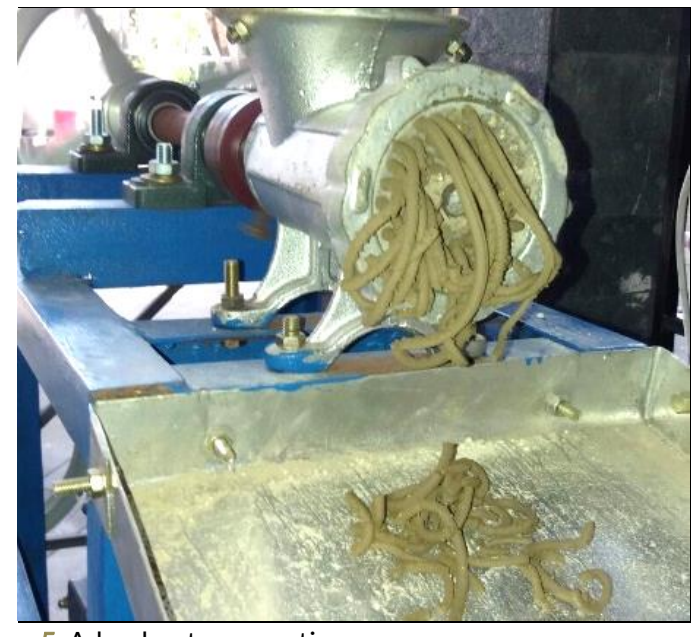

Figure 5. Adsorbent preparation

The adsorbent has been successfully made (Figure 5) and tested to purify patchouli oil (Figure 6) on a laboratory scale. The result showed in Table 2 which according to SNI 2006, the adsorbent has proven to effectively reduce the acid number of patchouli oil from 3.53 to 0.86 or decrease by $75.6 \%$. In addition, Fe content in oil decrease by $1.34 \%$ from $0.373 \mathrm{mg} / \mathrm{kg}$ to 0.368 $\mathrm{mg} / \mathrm{kg}$.

Table 2. Results of Patchouli Oil Characterization According to SNI 2006

\begin{tabular}{|c|c|c|c|c|c|}
\hline Parameters & SNI & $\begin{array}{c}\text { Initial } \\
\text { Patchouli Oil }\end{array}$ & B (300) & $\begin{array}{c}\mathrm{NaHCO}_{3} \\
(300)\end{array}$ & $\begin{array}{c}\text { B20-NaHCO } \\
(300)\end{array}$ \\
\hline Color & $\begin{array}{l}\text { light yellow-reddish } \\
\text { brown }\end{array}$ & light yellow & light yellow & light yellow & light yellow \\
\hline Specific gravity & $0,950-0,975$ & 0,9548 & 0,9554 & 0,9556 & 0,9554 \\
\hline Refractive index & $1,507-1,515$ & 1,53 & 1,54 & 1,53 & 1,51 \\
\hline $\begin{array}{l}\text { Solubility in ethanol } \\
90 \%\end{array}$ & $\begin{array}{l}\begin{array}{l}\text { Clear solution } \\
\text { volume ration } \\
1: 10\end{array} \\
\text { of }\end{array}$ & $1: 1$ & $1: 1$ & $1: 1$ & $1: 1$ \\
\hline Acid number & Max. 5 & 3,53 & 2,57 & 0,86 & 0,86 \\
\hline Ester number & Max. 20 & 34,78 & 19,26 & 8,61 & 10,77 \\
\hline Optical rotation & $(-) 48^{\circ}-(-) 65^{\circ}$ & $\ldots$ & $\ldots$ & $\ldots$ & $\ldots$ \\
\hline $\begin{array}{l}\text { Patchouli alcohol } \\
(\%)\end{array}$ & Min. 30 & $32,06 \%$ & $32,75 \%$ & $35,12 \%$ & $34,53 \%$ \\
\hline Fe content (mg/kg) & Max. 25 & 0,373 & 0,631 & 0,515 & 0,368 \\
\hline
\end{tabular}

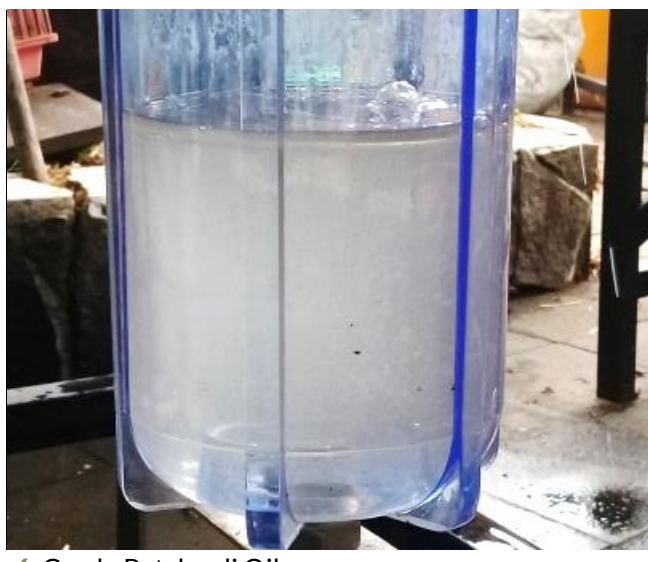

Figure 6. Crude Patchouli Oil

\subsection{Transfer of technology to Surya Wulan SME}

The distiller which has been successfully tested in CV. Fruitanol Energy then was ready to be installed at Surya Wulan SME. Also, training on patchouli oil processing was conducted with Surya Wulan SME members and patchouli oil business actors in Gerbosari Village, Kulonprogo.

\section{CONCLUSION}

An energy-saving distiller of patchouli oil has been successfully manufactured with a capacity of $15 \mathrm{~kg}$ of 
dried patchouli leaves that has been applied in CV. Fruitanol Energy and Surya Wulan SME. The distiller can increase SME's productivity since it can shorter distillation time, lower production cost, less heat loss, and less human power and exhaustion.

Bentonite modified $\mathrm{NaHCO}_{3}$ adsorbent has been successfully produced and used as a laboratory-scale patchouli oil purifier. The adsorbent can decrease the acid number of crude patchouli oil and improve oil quality as well as meet the SNI after being tested.

This technology needs to be further refined, specifically in the design of the tube cover. Wherein the use of nuts and bolts can be reduced and combined with other techniques so that the process of closing and opening the cover of the distiller does not require a long time.

\section{ACKNOWLEDGMENT}

The authors would like to express gratitude towards the Directorate of Community Service of UGM for the Research-Based Community Service Grant and Utilization of Appropriate Technology in 2018, as well as Surya Wulan SME and CV. Fruitanol Energy for their facilities and cooperation.

\section{REFERENCES}

Chaidir, A. (2009). Ignatius Susilo: dari Samigaluh Menjaga Mutu. Majalah Trubus.

Jaramillo-García, V., Trindade, C., Lima, E., Guecheva, T. N., Villela, I., Martinez-Lopez, W., Corrêa, D. S., Ferraz, A., Moura, S., Sosa, M. Q., Da Silva, J., \& Henriques, J. (2018). Chemical characterization and cytotoxic, genotoxic, and mutagenic properties of Baccharis trinervis (Lam, Persoon) from Colombia and Brazil. Journal of ethnopharmacology, 213, 210-220. doi: 10.1016/j.jep.2017.10.027

Howarth, J. (2015). Natural product supply bulletin: patchouli, Mexican lime and the Crimean conflict, Perfum. Flavor., 40, 32-37.

Kusuma, H.S. and Mahfud, M. (2016). Comparison of conventional and microwave-assisted distillation of essential oil from Pogostemon cablin leaves: Analysis and modelling of heat and mass transfer. Journal of Applied Research on Medicinal and Aromatic Plants, 4, 55-65. doi: 10.1016/j.jarmap.2016.08.002.

Kusuma, H. S., Altway, A., and Mahfud, M. (2018). Solvent-free microwave extraction of essential oil from dried patchouli (Pogostemon cablin Benth) leaves. Journal of Industrial and Engineering Chemistry, 58, 343-348. doi: 10.1016/j.jiec.2017.09.047

Lawrence, B. M. (2009). A preliminary report on the world production of some selected essential oils and countries, Perfum. Flavor., 34, 38-44.

Marbun, J. (2014, Maret 23) Kulon Progo Kembangkan Budidaya Tanaman Nilam. Republika. Diakses dari https://republika.co.id/berita/nasional/jawatengah-diy-nasional/14/03/23/n2vjgu-kulonprogo-kembangkan-budidaya-tanaman-nilam

Rahmayanti, D., Hadiguna, R. A., Santosa, and Nazir, N. (2018). Determining the Profit of "Patchouli Oil" Supply Chain: A Case Study in Indonesia. International Journal on Advance Science Engineering Information Technology, 8(2), 483488. doi: 10.18517/ijaseit.8.2.3485

Setiawan dan Rosman, R. (2013). Status Penelitian dan Upaya Peningkatan Kadar Patchouli Alkohol Pada Minyak Nilam, Perspektif, 2(12), 101.

Zhao, Z., Lu, J., Leung, K., Chan, C. L., \& Jiang, Z. H. (2005). Determination of patchoulic alcohol in Herba Pogostemonis by GC-MS-MS. Chemical \& pharmaceutical bulletin, 53(7), 856-860. doi: 10.1248/cpb.53.856 